Submitted to Fitz-Gibbon, K. and Walklate, S. (eds) (2016) Homicide, Gender and Responsibility: International Perspectives. Routledge.

\title{
Attributing Criminal Responsibility for Workplace Fatalities and Deaths in Custody: Corporate Manslaughter in Britain and Ireland
}

\section{David M. Doyle and Joe McGrath ${ }^{1}$}

This chapter examines the divergent means of imposing criminal responsibility for corporate manslaughter in two comparable common law jurisdictions: Ireland and England and Wales. First, it explores the methodological limitations of gauging the true extent of work-related fatalities in both jurisdictions and investigates, insofar as is possible, the interplay between gender and workplace deaths across selected member states of the European Union (EU). Secondly, the chapter traces the development of the law of corporate manslaughter from the imposition of corporate criminal liability via the common law "identification doctrine" to the proposals for law reform in Ireland and the introduction of a direct corporate liability homicide offence in the United Kingdom (UK). Thirdly, the chapter accepts the challenge set by Jeremy Horder to take "the intellectual leap out of the Marxist moral-political rut in which corporate manslaughter scholarship has largely been stuck" and explores a provision of the Corporate Manslaughter and Corporate Homicide Act 2007, which has been neglected by criminologists and criminal law scholars - the application of the legislation to deaths to custody - an aspect of the Act, which was unsurprisingly very controversial at the time (Horder, 2012: 116). Building on the literature that examines the applicability of the 2007 legislation to National Health Service Trusts (Horder, 2012) and to the police (Griffin and Moran, 2010), this chapter opens up

\footnotetext{
${ }^{1}$ The authors thank Professor Paul Almond, Professor Mary Bosworth, Professor Shane Kilcommins and the reviewers for their comments on earlier drafts of the chapter. The usual disclaimers apply.
} 
this area of inquiry in a context where it has hitherto been unexplored and investigates the potential liability of HM Prison Service (HMPS) as an organisational body in light of the statute.

\section{Work-Related Fatalities in Comparative Perspective}

Homicide (whether murder, manslaughter or infanticide) is one class of violent crime where the contemporary police figures in Ireland and the UK are considered to provide a reasonably accurate count (Office for National Statistics, 2015: 27). As Ian O'Donnell observes, it would be wholly exceptional for an unlawful death not to be thoroughly investigated or not to be contained in the official figures ( $O^{\prime}$ Donnell, 2002). The limitations of crime statistics more generally have been well documented, but the interpretation of workplace fatality statistics is also laden with methodological difficulties (Almond, 2013: 11-14). Although work-related fatalities do not appear to be subject to the same under-reporting issues as non-fatal accidents in the workplace, it can be stated with some confidence that the true extent of work-related deaths is not reflected in the official statistics. For instance, deaths resulting from work-related road traffic collisions and long-term occupational illnesses such as cancer are excluded from the fatality statistics in Ireland and the UK (Drummond, 2007; 2008; HSE, 2015). Attributing chronic illnesses and deaths to occupational exposure is almost impossible given the genuine difficulties with case identification - "diseases processes are often complex, multi-causal and can have a long latency period" (Russell et al., 2015: 21) - but work-related road traffic deaths are also difficult to quantify due to limitations in data collection systems 
(Drummond, 2007: 6). This is so even though a growing body of literature indicates that road traffic fatalities contribute significantly to, and in certain common law jurisdictions, comprise the largest single category of work-related injury deaths (25). It thus seems reasonable to surmise that the range of work-related deaths that come to the attention of the Health and Safety Executive (Britain) and Health and Safety Authority (Ireland) only provide "a consistent record of a subset of work-related injuries and deaths" (Russell et al, 2015: 21).

Yet despite these limitations, the "official" figures reveal that there are almost as many workplace deaths as homicides in Ireland annually (Kilcommins et al., 2004: 130). "Sadly", as the Chief Executive of the Irish Health and Safety Authority (HSA) pointed out, "there were 48 work-related deaths in 2012" (HSA, 2012: 3), while there were sixty cases of murder and manslaughter in the same year. This, of course, is not to suggest that all workplace deaths can be attributable to employers breaking the law, but it does appear that Irish citizens are almost as likely to be "wounded or killed at work, sometimes because their employer has broken the law, than they are to be attacked and harmed by a stranger" (Kilcommins et al., 2004: 130). Furthermore, while at least there is some possibility that such an assailant may be detected and prosecuted, "[there] has never been a prosecution of a corporate entity for manslaughter in Ireland" (LRC, 2005: 4). At the time of writing, there is still no Corporate Manslaughter legislation on the Irish statute book, although the Law Reform Commission has recommended its introduction (Carolan, 2011: 157-174) and the latest of a series of private members' bills was introduced in the Seanad in June 2013. By contrast, an entirely new homicide offence that can only be committed by 
organisations was enacted in the UK in 2007. This direct corporate liability homicide offence marked the abandonment of the identification principle as the method of attributing liability to companies and organisations who may now be held criminally responsible for "unlawful homicide where previously there was no unlawful homicide and no homicide offence committed by anyone" (Ormerod and Taylor, 2008: 591). The UK is not the only jurisdiction to create a specific homicide offence for corporations that cause death - the Australian Capital Territory (ACT) introduced an offence of this type in 2003 - but the legislative act of passing an offence into law does not necessarily mean that the provision will be implemented in practice (Almond, 2013: 35-37). There were, for instance, only 6 offences of corporate manslaughter recorded in England and Wales in the four-year period after the legislation came into force in April 2008 (Office for National Statistics, 2012). This chasm is particularly apparent when the police statistics are juxtaposed with the workplace fatality statistics. To put it otherwise, there were 114 fatal injuries in the workplace between March 2011 and April 2012, but there were only 2 corporate manslaughter offences recorded in the same 12-month period (Office for National Statistics, 2012). By contrast, there were almost five times as many homicides in the UK as deaths in the workplace (550 and 114 respectively), although it would appear to be stretching credulity to suggest that only two of these work-related fatalities were the outcome of gross negligence or blatant law breaking (Office for National Statistics, 2012).

The examination of national data comparability on accidents at work also poses serious methodological challenges (Brenner and Hopkins, 2006: 10-12). International 
comparisons are fraught with difficulty due to differences in definitions of workplace accidents and reporting systems inter alia, but some basic insights can be attained from the European Statistics on Accidents at Work (ESAW) collected by the Statistical Office of the EU, Eurostat (HSE, 2015: 7-8). Similar to the steady overall reduction in work-related deaths across the EU, the reports of the HSA and the HSE illustrate that there has been a downward trend in the rate of work-related fatality in Ireland and the UK in the period 1998-2013, although the decline has become somewhat less pronounced in the UK in more recent years (HSE, 2015: 2; Russell et al., 2015: 72). Yet despite the decrease in the number of reported workplace fatalities between 1998 and 2013, Ireland had the eight highest workplace fatality rate in the EU15 Countries in 2012, with more than twice the UK rate of workplace fatalities per 100,000 workers (Eurostat, 2012). The standardised fatality incidence rates in 2012 vary significantly among the EU15 civil law jurisdictions ranging between 0.72 in the Netherlands and 2.71 in Portugal. Other civil law jurisdictions such as Sweden (0.80), Germany (0.90) and Denmark (1.18) also have low fatality rates, while the Irish rate (1.43) remains relatively stable, hovering just above the national EU15 average. By contrast, the standardised incidence rate for the UK $(0.58$ per 100,000$)$ was considerably lower than the corresponding EU15 rate (1.3) and that of many other EU member states, including Italy (1.29), Spain (1.99) and France (2.64). Table 1 shows the latest standardised rates of fatal accidents at work published by Eurostat.

\section{[Insert Table 1]}


What is also clear from the Eurostat data is that there is a strong gender difference in the standardised fatality incidence rates. The 2012 statistics reveal that the risk of fatal accidents is quite unequal between males and females across the EU15 countries and that the female fatality rate is relatively low ( 0.12 per 100,000 workers in 2012) when compared to the male fatality rate (2.02 per 100,000 workers). All told, there were 1402 fatal accidents recorded in the EU15 countries in 2012, 48 of which were female fatalities. It is evident, therefore, from this succinct analysis that the problem of (reported) workplace fatalities in the EU15 countries is predominately a male one with the available statistical evidence revealing that women were less likely than men to die at work. Of course, this disparity between the sexes is partially explained by "employment patterns within occupations and industries", but it does appear that this is not a uniquely European trend (Hoskins, 2005: 37; BLS, 1994-2013).

\section{Attributing Corporate Criminal Responsibility in Britain and Ireland}

Although there is an increasing clamour to criminalise organisations who are in some way responsible for workplace deaths, the criminal law was "developed with fleshand-blood human beings in mind" so offences, and serious offences in particular, generally require both an illegal conduct element (actus reus) and a "guilty mind" element (mens rea) (Gobert, 2008b: 61). As companies do not have minds of their own, the law has struggled to find coherent, consistent and fair methods to ascribe fault to companies (Gobert, 1994: 393; Wells, 2001: 86-99). Criminal liability may, however, be imposed via the identification doctrine where a sufficiently senior 
manager, the "directing mind and will" of the company, has perpetrated the crime or bears responsibility for the crime. In Lennard's Carrying Co. Ltd v Asiatic Petroleum Co. Ltd ([1915] AC 705: 713), a case concerning civil liability under statute for goods lost at sea, Lord Haldane LC noted the difficulties of locating a "directing mind" in a company, stating "its active and directing will must consequently be sought in the person of somebody who for some purposes may be called an agent, but who is really the directing mind and will of the corporation, the very ego and centre of the personality of the corporation". In HL Bolton (Engineering) Co. Ltd v TJ Graham \& Sons Ltd ([1957] 1 QB 159), concerning a statutory entitlement to renew a lease, Lord Denning developed the basis for the doctrine by analogising the company with a human. He noted (172) that servants and agents are merely the hands of the company but the directors and managers are the brains of the company "who represent the directing mind and will of the company, and control what it does. The state of mind of these managers is the state of mind of the company and is treated by the law as such".

These dicta were subsequently cited in Tesco $v$ Nattrass ([1972] AC 153), a prosecution for false advertising. Lord Diplock (199) noted that the company itself may set out who acts as the directing mind and will of the company in its memorandum of association, though the actions of its board of directors, or through its shareholders at the general meeting. Viscount Dilhorne (187) stated that such a person or persons would have "actual control" of the company or some of its actions though exactly who constitutes the directing mind and will of a company would naturally vary from company to company. Lord Reid (171) noted that these persons 
include the directors, the managing director, and senior officers of the company who "carry out the functions of management and speak and act as the company" but that this would generally exclude "subordinate" officers because "they carry out orders from above and it can make no difference that they are given some measure of discretion".

The identification doctrine has been successfully invoked to prosecute small companies or "one-man" companies, where the actions of the company are easy to associate with the manager. For example, in $R v$ Kite and OLL Ltd ([1996] 2 Cr. App. R.(S.) 295), a small company with an uncomplicated management system was convicted of the deaths of four school children who drowned in a canoeing accident because its managing director knew the safety systems in place were inadequate (McShee, 2008: 12). Similarly, in $R v$ Jackson Transport (Osset) Ltd (Health and Safety Bulletin, November 1996), the one-director company was convicted of manslaughter because it had not provided equipment and training to an employee who died when sprayed with toxic chemicals while cleaning a tanker. It has, however, been more difficult to successfully prosecute larger companies, with more complex systems for organising responsibility (Sealy and Worthington, 2010: 145).

In $R \vee P \& O$ Ferries ([1991] 93 Cr. App. R. 72), the company was acquitted of corporate manslaughter when one of its ferries capsized while sailing with its doors open, killing 193 people, because none of the other natural defendants facing manslaughter charges could be identified as the controlling mind and will of the company. This was the case despite a previous inquiry conducted by Sheen J which 
concluded, "all concerned in the management, from the members of the Board of Directors down to the junior superintendents, were guilty of fault in that all must be regarded as sharing responsibility for the failure of management. From top to bottom the body corporate was infected by the disease of sloppiness" (Department of Transport, 1987: 14). Similarly, in Attorney-General's Reference (No 2 of 1999) ([2000] 2 Cr App R 207), a large company employing 2,700 people was prosecuted for manslaughter when a high-speed train and a freight train collided killing seven passengers. The company had allowed the trains to operate with the safety systems turned off but it was acquitted because no specific "directing mind" could be found liable for manslaughter.

Convictions for manslaughter against large companies are hard to achieve because their organisational structures, their internal lines of decision making and accountability, the geographical scope of their operations and the nature, volume, complexity of their transactions, can all give rise to ambiguities such that responsibility can become diffused and fragmented throughout these organisations (Wolgast, 1992; Minkes and Minkes, 2008). In large corporations, for example, senior managers cannot be involved in all aspects of the daily business of the company so they set policies that are implemented by lower-level officers. This can mean, "the subordinate has worked out all the details of the boss's predetermined solution, without the boss being specifically aware of all the eggs that have to be broken", a solution that "relieves superiors of too much knowledge, particularly guilty knowledge" (Jackall, 1988: 20). This may insulate managers from the criminal actions of subordinates, so that "a business inevitability is converted into a legal defence" 
(Gobert, 1994: 401).

As regards the Irish jurisprudence, Horan (2001: 30) notes that "there is an absence of comprehensive judicial scrutiny in this jurisdiction on the identification doctrine", though there are a number of civil cases which identify the actions of corporations with their senior officers. In $R v$ Justices of County Cork ([1906] 2 IR 415), concerning an application for a beer dealing licence by Beamish \& Crawford Ltd, it was suggested the acts, omissions, and reputation of the company could be inferred through that of its management. In Taylor $v$ Smith ([1991] 1 IR 142: 166), a case concerning whether a company could commit conspiracy with its "sole controlling agent and mind of the company", McCarthy J cited with approval Viscount Haldane LC in Lennard's, noting that the company acts through natural persons that are the directing mind and will of the company. In Superwood Holdings plc $v$ Sun Alliance and London Insurance plc [1995] 3 IR 303), the Supreme Court determined that a company could potentially be civilly liable for insurance fraud where it was possible to identify that the directing mind and will of the company was responsible for it. While noting Ussher's (1986: 38 ) warning that "attempts to relate parts of an organisation to corresponding parts of the human body was a medieval pastime", Denham J (330) cited and accepted the directing mind test in Lennard's Carrying Co. Ltd noting that "the appropriate test is to apply the essential principle expounded by Lord Haldane to an Irish company in a practical manner and determine who was in control of the relevant issue." In Howard v Irish Life \& Permanent ([2006] IEHC 419), a case concerning an order for costs sought by the Revenue Commissioners, the case law on the identification test is not cited but O'Sullivan J appeared to accept the 
principle, stating, "it would be unfair if, for example, knowledge in the possession of an employee of a branch of the respondents were to be imputed in the present context to the respondent itself in the absence of any evidence that this knowledge constituted the directing mind and will of the respondent".

Drawing these threads together, the current status of the identification doctrine in criminal cases is unclear in Ireland. Horan (2011: 33) cautions, "the decisions in Howard, Superwood and Taylor were not concerned with criminal liability and accordingly these precedents are not necessarily authorities in support of the identification doctrine in the context of corporate criminal liability nor do they preclude the option of the attribution doctrine". Nevertheless, it is of note that the identification doctrine has been endorsed in civil cases in Ireland and a number of English authorities seem to indicate that the doctrine is applied in criminal and civil law in the same way because it "has been developed with, no divergence of approach, in both civil and criminal jurisdictions, the authorities being cited indifferently in the other" (El Ajou v Dollar Land Holdings plc [1994] 2 All ER 685; Meridian Global Funds Management Asia Ltd v Securities Commission [1995] 2 AC 500).

More recently, in Meridian Global Funds Management Asia Ltd $v$ Securities Commission ([1995] 2 AC 500), the Privy Council seems to have taken a broader approach to attributing criminal liability to companies in a case concerning the failure to register the purchase of securities as required by statute in New Zealand. The Court of Appeal determined that the rules by which acts are attributed to 
companies, the rules of attribution, are determined by the specifics of the companies constitution, the rules implied by company law, the rules of agency and vicarious liability. However, these rules may not always provide comprehensive instructions so the court "must fashion a special rule of attribution for the particular substantive rule ... [to determine] whose act (or knowledge or state of mind) was for this purpose intended to count as the act etc. of the company" (507). The court concluded that the purpose of the substantive rule in this instance was to ensure immediate disclosure, in fast moving markets, of the identities of those buying large volumes of shares in public issuers. In order to prevent the law being frustrated, the court could infer intention to the company from the person authorised to perform the transaction, even if he was not the directing mind and will of the corporation. Otherwise the company would not have to report these transactions until senior management were aware of them and that "would place a premium on the board paying as little attention as possible to what its investment managers were doing" (511).

This broader approach, which has proven popular in other common law jurisdictions (Forlin and Smail, 2013: 502), was sharply circumscribed in Re Attorney General's Reference (No. 2 of 1999) ([2000] 2 Cr App R 207). The Court of Appeal determined that the identification doctrine was the only appropriate test for ascribing criminal liability for gross negligent manslaughter to companies. The directing mind and will of the company had to have been grossly criminally negligent as a pre-condition to criminal liability. Rose LJ (211) explained that the identification theory "was developed in order to avoid injustice: it would bring the law into disrepute if every 
act and state of mind of an individual employee was attributed to a company which was entirely blameless". The broader approach taken in Meridian, when it was required, was only appropriate for statutory offences that would otherwise be frustrated and identification remained the appropriate doctrine for ascribing liability for common law offences. This was the view of the court despite the fact that the identification doctrine was originally developed to address statutory offences (Gobert and Punch, 2003: 69).

Similarly, in St. Regis Paper Co. Ltd v The Crown ([2012] 1 Cr. App. R. 14), a prosecution for filing false environmental pollution reports, the Court of Appeal applied the stricter identification doctrine detailed in Tesco. It determined that it was not necessary to relax the approach in Tesco in order to avoid "emasculating" the legislation, noting that the company had already been convicted on fourteen counts of strict liability offences (184). Moses LJ (185) determined that the "conventional approach" was to apply Tesco and ask whether the Technical and Environmental Manager, was "in actual control of the operations of the company in relation to the submission of records and not responsible to another person for the manner in which he discharged his duties in the sense of being under that other person's orders?" As this manager reported to numerous layers of management above him, and acted in defiance of the companies clear environmental policy standards, the court determined that he did not fall "within the category described by Viscount Dilhorne as someone who was in actual control of the operations of a company or part of them and not responsible to another person in the company for the manner in which they were discharged" (185). 
It is difficult to state with complete certainty whether it is the identification principle in Tesco or the attribution principle in Meridian that ought to apply, not only because Meridian may only apply to statutory offences, but also because its application seems to turn on the statute being interpreted (Ashworth, 2009: 150). The impact of the wider Meridian approach in Ireland is also still unclear, though it has been referenced briefly in a number of Irish cases. In Crofter Properties Ltd $v$ Genport Ltd ([2002] IEHC 26), McCracken J cites the rules of attribution detailed by Hoffman $\sqcup$ in Meridian and though the parties seemed to accept them, the Court did not actually consider the issue in further detail. In Fyffes $v$ DCC [2009] 2 IR 417], a civil action for insider dealing, Laffoy J cited Viscount Haldane LC in Lennard's and noted that it was applied by the Supreme Court in Superwood. She further cited Hoffman in Meridian noting that in cases where the application of the directing mind and will test would defeat the purpose of the substantive rule, that the court could fashion special rules attributing intent to companies. However, specific statutory provisions determined the attribution of liability in this case so Meridian was not applied.

\section{Gross Negligence Manslaughter}

Companies cannot form subjective intent or be subject to the mandatory life sentence in prison, so companies cannot commit the offence of murder in English and Irish law (Wells, 2001: 109; LRC, 2003: 89-90). By contrast, companies may commit gross negligence manslaughter at common law. The House of Lords laid down the test for gross negligence manslaughter in $R v$ Adomako ([1995] 1 AC 171). 
In that case, an anesthetist did not notice that the tube from a ventilator became dislodged during eye surgery causing the patient to have a cardiac arrest and die. Lord Mackay determined that the jury could make a determination of gross negligence manslaughter where the defendant had breached his duty of care and that breach had caused the loss of life, provided that the breach amounted to gross negligence. In making that determination, the jury would have to consider the extent to which his conduct departed from the proper standard of care, given all the circumstances in which he found himself at the time. In $R v$ Misra and Srivastava ([2004] EWCA Crim 2375), where a patient died when he was not treated for an infection following routine knee surgery, the Court of appeal subsequently determined that this test did not breach Article 7 of the European Convention of Human Rights (ECHR) for lack of certainty.

The Irish courts have also considered cases of gross negligence manslaughter resulting in deaths by actions or omissions. In DPP $v$ Dunleavy ([1948] IR 95), the Court of Criminal Appeal laid down the test for gross negligence manslaughter. In that case, a taxi driver killed a cyclist when he was driving on the wrong side of the road with his headlights switched off at night. Davitt J in the Court of Criminal Appeal, while noting that manslaughter by negligence is difficult to precisely and concisely define for all circumstances, stated that the test is whether the accused fails to observe standards thought objectively necessary in the circumstances, where the negligent act results in death, and the fatal negligence was of a very high degree involving the risk or likelihood of substantial personal injury to others. This test was subsequently endorsed and applied in The People (DPP) v Cullagh (Unreported, 
Court of Criminal Appeal, 15 March 1999), a case in which a child was killed when a rusty cable holding a chairoplane at a funfair snapped. More recently, noting that this offence was not unconstitutional for vagueness, Charleton J in Joel v DPP ([2012] IEHC 295) reiterated, "criminally negligent manslaughter arises where the death of another person is caused in circumstances which objectively amount to a very high degree of negligence and which, in the circumstances in question, to any reasonable person the fact that a serious risk was unjustifiably taken with the life of another would be apparent".

Despite a clearly articulated test for gross negligence manslaughter, there is no record of a successful prosecution being taken against companies for this offence in Ireland. Identifying this as a lacuna in the law, the Law Reform Commission recommended the introduction of a new statutory offence of corporate manslaughter, based on the common law offence of manslaughter by gross negligence, formulated around a breach of duty as set out in Dunleavy (LRC, 2005: 15-19). The offence would apply to all "undertakings", where this means "a person being a body corporate or an unincorporated body of persons engaged in the production, supply or distribution of goods or, the provision of a service whether carried on for profit or not" (116). It sets out a restructured version of the identification doctrine to address the "paradox of size", whereby the doctrine operates to "disproportionately affect small organisations where the controlling mind is easy to identify" (29). The actions of "high managerial agents", including directors, managers or other similar officers or persons who purport to act as such, are considered in determining whether there has been a breach of duty but they do 
not have to be the directing mind and will of the corporation. The court may also have regard to a wide variety of factors, including the regulatory environment in which the entity is operating. Companies convicted of this offence may be subject to an unlimited fine, determined by the court. High managerial agents may be subject to accessorial liability for "grossly negligent manslaughter causing death" if the company has already been so convicted. These agents may be subject to an unlimited fine, a period of disqualification as the court sees fit, and imprisonment of up to 12 years. Though an attempt was made to pass a version of this Bill in 2007, this effort lapsed. Reflecting on the failure to pass legislation in this area, McGrath (2015: 117) observes, "this was a period of talk, inquiry, investigation and consciousness-raising but often not of action or change. The need to address corporate wrongdoing was beginning to enter the consciousness of legislators and citizens alike but the efforts to act on these sentiments lacked commitment".

By contrast, though its introduction was also significantly delayed, the Corporate Manslaughter and Corporate Homicide Act was enacted in the UK in 2007 (Gobert, 2008a). Despite its title, however, the offence can be committed not only by public and private companies, but also by unincorporated organisations, including government departments and public bodies, as specified in Schedule 1 to the Act. The legislation specifically provides that a duty of care is owed to anyone who is detained at a "custodial institution" (CMCHA, s2(7)). Most of the legislation entered into force on the $6^{\text {th }}$ of April 2008 though the custody provisions were not effective until the $1^{\text {st }}$ of September 2011 to allow the relevant organisations to prepare for their application (SI 2011/1867). The Act abolishes the existing common law offence 
of gross negligence manslaughter for companies and though individuals cannot be held liable under the Act, they remain subject to the common law on manslaughter and health and safety law. Relevant organisations are guilty of the new offence, "if the way in which its activities are managed or organised (a) causes a person's death, and (b) amounts to a gross breach of a relevant duty of care owed by the organisation to the deceased" (CMCH Act sections $1(1)(a)$ and $1(1)(b))$. By looking at the organisation as a whole, rather than a particular layer of management, "the old limitations of the identification doctrine are gone ... It will now be possible to examine the shortcomings of a wide variety of individuals within the organisation to prove a failure of management by the organisation ..." (Ormerod and Taylor, 2008: 602). However, the offence can be committed, "only if the way in which its activities are managed or organised by its senior management is a substantial element in the breach" (CMCH Act sections 1(3)), a construction that does not make the actions of the non-senior managers irrelevant, provided they do not render the senior managers actions less than substantial (Ormerod and Taylor, 2008: 604). The breach is gross, "if the conduct alleged to amount to a breach of that duty falls far below what can reasonably be expected of the organisation in the circumstances" ( $\mathrm{CMCH}$ Act section 1(4)(b)). A person is involved in "senior management" if they "play significant roles in (i) the making of decisions about how the whole or a substantial part of its activities are to be managed or organised, or (ii) the actual managing or organising of the whole or a substantial part of those activities" (s.1(4)(c)). As such, the legislation implements a "qualified aggregation principle" because it characterises "the companies management failure as the aggregate of those (groups of) individuals' failures; and (2) because whilst the failures might be found in and 
aggregated from a variety of places within the company, there is a proviso or qualification that failures must include to an appropriate (substantial) extent, failure or failures by senior management" (Ormerod and Taylor, 2008: 594-595). The mechanism for attributing liability is therefore broader than that of the identification doctrine. An individual natural person, as a directing mind and will of the company, does not need to be found criminally liable for the death in question in order for the company to be held criminally responsible. The organisations can be punished by unlimited fines, remedial orders and adverse publicity orders (CMCH Act, ss.1(6), 9, and 10).

The enforcement of the legislation has, however, been limited and uneven. Field and Jones (2013: 239-246) note, "the Government's Regulatory Impact Assessment projected that the Act will not generate more than 10 to 13 successful prosecutions per annum, despite the fact there are on average 196 workers per year fatally injured in the United Kingdom". In fact, however, only six cases had concluded by late 2014 and all offenders were small companies, despite the fact that the legislation was designed to make it easier to prosecute large companies with more complex organisational structures (Field and Jones, 2014: 158). Just one of these involved the successful prosecution of a company for the death of a non-worker in circumstances where an eleven year old girl was struck by a ski-boat (R. v Prince's Sporting Club Ltd Unreported November 22, 2013 (Crown Ct (Southwark)). Moreover, there was merely one trial (the other five corporate offenders had pleaded guilty), suggesting that the State had pursued only the most obvious and egregious cases. It seems likely that this is not for a lack of bad-enough cases, but 
"the result of those with responsibility to investigate and prosecute lacking the necessary resources, co-ordination and training" (Slapper, 2015: 92). It has also been suggested that "there has been a clear trade-off between guilty pleas for the $\mathrm{CMCH}$ charge and dropping those against individual directors (whether for manslaughter or health and safety offences)" because those charges have been withdrawn when such corporate guilty pleas were entered (Wells, 2014: 861). Moreover, the offenders have been subjected to fines less than the $f 500,000$ minimum penalty recommended by the Sentencing Guidelines Commission (Sentencing Guidelines Council, 2010: para. 24). Accordingly, the evidence suggests that prosecutions for corporate manslaughter remain overwhelming directed at small privately held companies for the deaths of their employees.

\section{The Custody Provision (Section 2(1)(d))}

The methodological deficiencies and technical complexities of the 2007 Act have been well rehearsed, but the "most controversial category of duty" in the legislation is, as Ormerod and Taylor (2008: 600) note, "that relating to duties arising from detention". Yet the fact that scholars have tended to focus on the duty owed by private companies to their employees, almost to the complete exclusion of the duty owed by custodial institutions to those detained, has meant that the application of the 2007 Act to the "ugly side of public service activity" has not been subject to much academic scrutiny (Horder, 2012: 115). This is particularly evident in the prison context where there has been a considerable number of reports over the last decade

that have repeatedly offered evidence of inadequate screening and formal risk 
assessment, not to mention insufficient and inexperienced staffing, overcrowded conditions and recurrent weaknesses in the implementation of the Prison Service suicide and self-harm prevention procedures (ACCT) (PPO, 2014a: 5; HMCIP, 2014: 29). Furthermore, there is evidence - despite the effect of deaths in custody on both the individuals and establishments involved (Liebling, 2002: 201-202) - that certain prisons still fail to give sufficient attention to implementing and reinforcing the recommendations of the Prisons and Probation Ombudsman, who investigates all deaths in prison custody, in fulfillment of the procedural duty under Article 2 of the ECHR (Owers, 2009: 1537). The "dangerous perpetuation of negligence, idleness, indifference, inefficiency and the arbitrary cost-cutting" does not, to use Horder's words, "only affect the safety of workers" (Horder, 2012: 116).

The clamour to ensure the applicability of the 2007 Act to the Prison Service and other "carceral" spaces can, however, be only properly understood when one places the number of custodial deaths in comparative perspective. For instance, there were 150 deaths among British workers (almost all of which occurred in the pursuit of private corporate activity) between April 2012 and March 2013 (HSE, 2015). By contrast, there were 182 deaths in prison custody in the same period, 51 of which were classified as "self-inflicted" (Ministry of Justice, 2014: 7). To put it another way, prisoners in this period were more likely to take their own lives than construction employees were to be killed at work (HSE, 2015). However, these statistics disguise the extent to which both workplace fatalities and self-inflicted deaths in prison custody are gendered. Although the rate of workplace fatality in Britain is one of the lowest in Europe, there were still 439 deaths among Britain's workers in the four- 
year period between April 2009 and March 2013 and most of the victims of workrelated fatal accidents were male. Similarly, there were 313 self-inflicted deaths in prison in the same period, of which 9 of the deceased were female. Thus, after the sharp upward trend in prison suicides by females between 1998 and 2003, the number has declined in recent years. In 2013, for instance, women represented 4.6 per cent of the prison population in the UK and accounted for 2.6 per cent of selfinflicted deaths. This marked a notable decrease to the figures presented by the Corston Report (2007), which was triggered by the self-inflicted deaths of six women at HMP Styal in a 12-month period between 2002 and 2003. The 2007 report highlighted that women represented only 6 per cent of the prison population in 2003, but that they accounted for 15 per cent of self-inflicted deaths (Corston, 2007: 19). In light of these figures, it seems reasonable to surmise that both workplace deaths and prison suicides have become predominantly a male preserve in the UK in recent years.

That said, it would be misleading to suggest that all self-inflicted deaths in prison custody can be attributable to grossly negligent management practices or to grossly negligent actions by prison staff, but it should also be borne in mind that a prisoner is almost entirely dependent on the respective prison to safeguard his or her health and safety during what may be a lengthy or an indeterminate sentence and that this should supersede the "countervailing considerations and warrants of placing the relevant organisation under an ongoing duty of care" (Horder, 2012: 137). This argument was perfectly encapsulated by Lord Hunt $(688$ HL Official Report (5th Series), col GC 187) who asserted that: 
The power lawfully to deprive an individual of his or her liberty must be one of the most serious responsibilities there can be. The duty of care owed to an individual in detention, where he cannot act freely in his own interests, is onerous and profound.

In this regard, it is also important to point out that the House of Lords in the case of ex parte Amin [2003] (UKHL 51, para. 21), the Zahid Mubarek case, was unanimous in rejecting the Government's argument, successful before the Court of Appeal, that "an allegation of negligence leading to death in custody, though grave enough in all conscience, bears a different quality from a case where it is said that the state has laid on lethal hands" and held that systemic failures leading to deaths called for even greater scrutiny. Lord Bingham, for instance, said "a systemic failure to protect the lives of persons detained in custody may well call for even more anxious consideration and raise even more intractable problems".

So by virtue of schedule 1, the offence of "Corporate Manslaughter" not only applies to private companies but also in some measure to all "public bodies the performance of whose functions are most likely to involve causing deaths" (Horder, 2012: 117). These include, inter alia, the Ministry of Defence, the Department of Health, and HMPS. Yet although the 2007 Act defines the scope of the duty, the nature of the duty is simply described as the duty owed under the law of negligence by the organisation to "someone for whose safety the organisation is responsible" (CMCHA 2007, s 2(1)(d)). Although it is well established in the law of tort that an 
organisation responsible for the detention of a person owes that person a duty to take reasonable care in respect of that person's health and safety, conjecture remains with regard to the exact extent to which that duty extends (Matthews, 2008: 66). Thus far, there has been no judicial consideration of the scope of the duty of care to prevent prisoner deaths at the hands of other prisoners, but the courts have held, in respect of self-inflicted deaths, that the duty to take reasonable care encompasses a duty to take reasonable steps to prevent a person from committing suicide, but only where the custodians knew or ought to have known that the individual prisoner was a suicide risk (66). The Court of Appeal in Orange v Chief Constable of West Yorkshire Police ([2002] QB 347: para. 43) did state, however, that given the increased risk of suicide among prisoners that there was an obligation, within the custodian's general duty of care for the prisoner's health and safety, to take reasonable steps to identify whether or not a prisoner presented a suicide risk. These decisions would suggest that the 2007 Act may only be applicable where the prisoner was being monitored under the Prison Service suicide and self-harm prevention procedures (ACCT) at the time of their self-inflicted death or where appropriate measures had not been taken to identify the known risk factors or "triggers" (PPO, 2014b).

What is more clear, however, is that the offence is only committed if the death is caused by the way in which the custodial institution's activities are managed and organised by its senior management and this must be a "substantial element" in the gross breach of a relevant duty of care to the deceased. The first limb of this definition is, as Griffin and Moran (2010: 370) observe, a "reflection of the common 
law 'directing mind' test", but the "second part of the definition removes any requirement on the part of a senior manager to possess a directing influence in the organisation or management of a relevant organisation's activities and policies". Accordingly, it would appear that the liability of a prison "may now ensue without the necessity of establishing that a senior manager obeyed policy or instructions dictated by the organisation's directing mind" (370). In other words, the prison service could potentially be prosecuted for manslaughter if gross failures of senior management cause the death of a detainee. Liability, however, appears to be excluded where the death is due to a public policy decision not to allocate appropriate resources to the Prison Service (CMCHA, s. 3(1); Horder 2012: 131-132).

The common law identification principle is also reformed further by virtue of the fact that an organisation's liability may now also be established by "aggregating the cumulative conduct of a collective of senior managers" (Griffin and Moran, 2010: 370). Although the concept of aggregation was rejected by the trial court in the Herald case, the 2007 Act appears to accept aggregated fault in a limited form and makes it possible to convict a prison on the basis of collective failings that must include, but are not restricted to, failings on the part of senior managers. Take, for example, the murder of Zahid Mubarek, who was killed by his cellmate, Robert Stewart, at Feltham Young Offenders Institution (YOI) in March 2000. Stewart had been "manifesting extreme racist views in correspondence, and was diagnosed during the criminal proceedings as a psychopath" (Keith, 2006: 6). On arrival at Feltham, Stewart was placed in a cell with Mubarek, and brutally attacked him with a wooden table leg. Had Feltham YOI been prosecuted for the death of Zahid Mubarek 
under the 2007 Act (had it been in force at the time) it is reasonable to assume that the case would have succeeded. In this regard, the findings of the subsequent investigation into the murder conducted by the Committee for Racial Equality (2003: 162) are particularly noteworthy:

Actions which should have protected Zahid were not taken because of the interaction of a number of factors. The pressure of prisoner numbers, the perception of staff shortages, limited resources and poor management had created a climate in which indifference, negligence, corner-cutting and noncompliance with specific and clear HM Prison Service requirements had become the norm.

S.8 of the Act also stipulates that juries must consider any evidence that shows an alleged breach of health and safety legislation. This may have particularly important consequences in the prison context where the Health and Safety at Work Act 1974 is largely inapplicable and cannot be invoked by prisoners who suffer breaches of it, even though Standing Order 6A (15) allows for prison inspections by the HSE and HMPS has been censured four times since 1999 (Livingstone et al, 2008: 232). This is also significant in that the Act states that should a violation of health and safety legislation be established, juries are permitted to take into account whether "attitudes, policies, systems or accepted practices within the organisation" were likely to have encouraged any failure to meet safety standards or produced a tolerance of it. Perhaps a crown censure would be sufficient evidence to show HMPS failed to comply with health and safety legislation, but as the dicta of Hooper J in the 
Mubarek case ([2003] UKHL 51: para. 26) indicates, evidence of a prison's culture and ethos may be decisive in certain cases involving deaths in custody:

Zahid Mubarek was murdered in Feltham by a racist cell mate with 'an alarming and violent criminal record, both in and out of custody'. It is accepted that Zahid Mubarek was put in the same cell as his killer because of 'systemic failures'. Established procedures were not followed and there is an appalling history at Feltham of failure to comply with earlier recommendations. It seems likely (and it is certainly arguable) that there were serious human failings both at the wing level and at higher levels which have not been publicly identified.

Yet despite the merits of the custodial provision, it seems plausible to argue that the "senior management" test renders section 2(1)(d) somewhat ineffective, because not only does it force "the inquiry back onto the issue of identifiable individuals" (Ormerod and Taylor, 2008: 604), it also fails both to acknowledge the reality of how the suicide prevention procedures work in UK prisons and the complexity of the organisational structure within HMPS.

\section{[Insert Figure 1]}

There are three levels of management in HMPS since the introduction of the new Fair and Sustainable working structures on the $1^{\text {st }}$ April 2013. The first-tier definition of senior management (in effect the "directing mind" of the prison) consists solely of 
the office of prison governor, while the second tier comprises Deputy Governors and invariably Heads of Function. Although the Senior Management Team (SMT) within a prison will be composed of members from both management tiers, proving a prison's liability based on the definition of "senior management" in the 2007 Act may, in fact, "mirror the difficulties" associated with establishing the guilt of private companies under the common law identification principle (Griffin and Moran, 2010: 371). For instance, the actual management control of the procedures to prevent deaths in prison custody are exercised in practice at a non-managerial level and it is difficult to envisage how a prison officer could meet the criteria specified in the Act in terms of "senior management". Furthermore, even in the occasional instances where management is involved, it is at the level of first line or third-tier management and a custodial manager - a "uniformed role" - would certainly not be classed as senior management within HMPS (NOMS, 2012: 8). Thus, in order to enable the Crown Prosecution Service (CPS) to establish a prison's liability for a death in a custodial setting, a custodial manager would have to be identified as a senior manager and involved in the suicide prevention process. This, of course, not only appears "unduly restrictive" and "threatens to open the door to endless argument in court as to whether certain persons do or do not constitute senior managers" (Clarkson, 2005: 683); it would also mean completely ignoring both the practical reality of the organisational hierarchy and the suicide prevention strategies within HMPS.

Furthermore, in its concentration on "senior management", the Act fails to take account of the individual failings of a wider range of individuals within the 
organisation. Various inquests, thematic reviews and Chief Coroner Reports to Prevent Deaths (previously Rule 43 reports) reveal that a substantial number of avoidable deaths in custody can be attributed to failures by lower ranking staff to properly implement the correct policies and procedures where a prisoner has been identified at risk. Of course, it could be argued that senior management must issue rules and guidance to staff, both orally and in writing, and that weaknesses in the implementation of the death avoidance procedures are at least partially attributable to a failure on the part of senior management to subject the processes to rigorous checks, but it should also be borne in mind that any case of corporate manslaughter must rest, as a prerequisite for success, on proof of a breach of a duty of care on the part of senior managers and that the senior management failure must be a substantial element in the breach of that duty. The term "substantial element" is not defined by the Act of 2007 but rather a question of fact for the jury who must determine as a matter of causation whether the culpability of a senior manager was more than minimal, "albeit not necessarily an absolute factor, in the breach of duty resulting in the person's death" (Griffin and Moran, 2010: 370). Therefore, other than in an unusual situation where a death in prison was directly attributable to a direction or instruction given by a Governor, a Deputy Governor or a Head of Function ("something that is not usual during standard ACCT procedures"), it would be very difficult for the CPS to establish a prison's liability for the offence of corporate manslaughter (PPO, 2014a: 19). Even where a custodial manager is involved in the ACCT process, the difficulty in identifying a line manager as senior management may nullify the intent of section $2(1)(d)$ and undermine the capacity of the Crown to successfully convict a prison for an avoidable death in custody. 
There are, of course, others aspects to be critical of in the 2007 statute as originally enacted. Many of the criticisms made by legal scholars such as the exclusive focus on organisational liability, the extension of the Act to such a diverse array of organisations, the exemptions to police officers and army officials, and the requirement of DPP consent to prosecute are persuasive and well founded. One eminent legal scholar (Gobert, 2008a: 415), for instance, has argued that:

... the extension of the bill in the final days before its passage to deaths in custody means that prisons can be prosecuted when deaths occur as a result of inadequate staff to provide comprehensive supervision of an undeniably violent prisoner population, where the inability to hire more staff is due to the budgetary constraints imposed by the government.

This example, he observes, is not intended to suggest that "prisons should not be held accountable when their gross negligence causes death", or that all prisoners who are willfully exposed to organisational gross negligence are not deserving of protection, but rather that other more appropriate types of criminal legislation than the law of corporate manslaughter might be constructed to cover these type of situations (415-416). The new approach also provokes the broader question of whether it is the conviction of companies and public bodies that is the most significant facet, or whether the punishment of organisations should be considered as important too (Ashworth and Horder, 2013: 154). A custodial institution can hardly be imprisoned, moderate fines can be swallowed up as operational costs, and severe fines may result in further reductions in the number of prison officers which 
would inevitably have deleterious effects on the safety and welfare of inmates. Finally, there is also some evidence, both in the corporate and the custodial context, to suggest that perhaps that the Act should have been extended beyond the limited (but high-profile) area of homicide (Gobert, 2008a: 419-422). Take, for instance, the remarks of Lord Ramsbottom, when speaking of Wormwood Scrubs during a debate on the Bill. Although observing that there was "no case of manslaughter", he recalled that "there was extraordinarily bad behaviour by staff, brutality of prisoners and, over a number of years, management failure on a scale that I simply could not believe" (688 HL Official Report ( $5^{\text {th }}$ Series), col GC 192).

Writing in 2008, James Gobert intimated that the symbolic significance of the 2007 Act may "ultimately transcend its methodological deficiencies" and that the primary value of the Act may very well lie in the very fact of its existence (2008a: 413). If nothing else, it was anticipated that the Act would, at least, spur the prison service and a variety of other custodial institutions to satisfy themselves that the structures and systems for preventing deaths in custody were fit for purpose and coerce them to take a fresh look at their culture and ethos in this regard (425-32). Furthermore, it was envisaged that the S. 2(1)(d) duty would encourage the Prison Service to afford greater compliance with safer custody practices as embodied in PSI 64/2011 and the ACCT document (v.5). As Lord Ramsbottom (688 HL Official Report (5 $5^{\text {th }}$ Series), col GC 193) put it:

I hate the thought of coercion through a Bill, but this Bill, which is based on the duty of care and which should be shown to everyone in the charge of 
these authorities, is an appropriate weapon. I seriously believe that the Bill would energise the management system in a way that nothing else that I have come across in the past 10 years seems to have been able to.

Yet despite such optimistic pronouncements, there were more self-inflicted deaths in prison custody in 2014 than at any time in the last 10 years ("reversing a downturn in the previous decade") (HMCIP, 2014: 25), the Prison and Probation Ombudsman has called for a review of the Safer Custody strategy and ACCT to see if they are still fit for purpose and the Corporate Manslaughter Act has not yet been invoked for a single death in prison custody (PPO, 2014a: 5). What is more, it appears that even if proceedings were instituted against a prison for a death in custody judicial interpretation of S. 2(1)(d), and more particularly the senior management test, may prove evidentially problematic. Although the management of a prison will ultimately fall under the rubric of the SMT, the death avoidance and ACCT procedures are implemented, at best, at line management level and invariably at a non-managerial level. While it may be a rational supposition for a jury, in determining the liability of a prison, to conclude that the responsibility for the breach of a relevant duty should logically be attributed to members of the SMT, it should be borne in mind that an ability to deflect liability exists in any large organisation that is characterised by a system of complex management and operational structures (Griffin and Moran, 2010: 371). Of course, the ability to deflect responsibility has always been, and still appears to be at least in the prison context, a major limitation on liability, and like its predecessor the "identification" principle did with medium-to large-size corporate bodies, it fails to take into account 
that crucial strategic and more importantly, operational decisions, are frequently not only delegated but assigned to lower levels of management and operations than those granted policy authority over the prison's affairs (371). Both independent and anecdotal evidence suggests that this is certainly the case with Safer Custody. It is, nonetheless, unacceptable that a prison could be able to escape liability for a completely avoidable death in custody, especially when the fault element for the crime was possessed by a custodial manager or a prison officer who had authority to take operational decisions, simply because that person was not a member of the SMT.

\section{Conclusion}

This chapter analysed the difficulties associated with criminalising the predominantly male phenomena of culpable workplace fatalities in both Britain and Ireland. It was shown that proving the directing mind of the organisation responsible for the manslaughter, as a precondition to corporate criminal liability, was often too difficult an obstacle to surmount when prosecuting large companies with complex management systems. The attribution doctrine, which did not require the directing mind to be culpable for the purposes of criminal liability, offered greater flexibility for prosecutors seeking to impose liability but it also suffered from vagueness and has been disfavoured as a means of imposing criminal responsibility in recent times. Although the proposed corporate manslaughter legislation in Ireland appears to have stalled indefinitely, the $\mathrm{CMCH}$ Act 2007 in the UK has embraced another method of attributing culpable misconduct to organisations. It adopted a "qualified 
aggregation" test, whereby an organisation may be guilty of corporate manslaughter when individual failures can cumulatively constitute corporate failure, provided that senior management failures were a substantial element in the breach of duty owed to the deceased. Nevertheless, though the legislation extended criminal liability to all relevant public bodies that cause death, not just companies, the legislation has, thus far, been enforced primarily against small private companies for employee fatalities in the workplace. The CPS has yet to target HMPS for a death in custody, even though more deaths occur annually in prisons than in the workplace. Moreover, it is impossible to relegate this failing to the past. This chapter has demonstrated that it may prove extraordinarily difficult to subject HMPS to criminal liability in the future, even where there is a willingness to initiate proceedings, because the legislation imposes a requirement that the actions of senior management must have played a substantial role in the breach of duty resulting in death. This is compounded by the fact that the procedures to prevent deaths in prison custody are invariably exercised by uniformed officers who play no role in the management of the prison.

In addition to the difficulties of securing convictions in practice, there is also the difficulty as to what punishments the State should impose on this kind of public body. The trite observation that convicted organisations have "no body to kick and no soul to damn" seems particularly ironic given that HMPS can hardly be imprisoned. Furthermore, it appears futile to fine a state-funded public body such as a prison, especially when this may reduce the resources it has available to safeguard the welfare and safety of prisoners and when the costs of such fines inevitably "spill- 
over" onto the taxpayer. The "spill-over" effect of punishment in more traditional corporate contexts has been well canvassed with the literature noting that the fining of corporations may be more likely to affect innocent parties removed from the wrongdoing than to punish management who are directly responsible for the crimes. Indeed, it has been argued that the costs of such fines are imposed on employees who suffer layoffs, consumers who are charged higher prices for products, and shareholders who do not receive dividends (Coffee, 1981; Fisse and Braithwaite, 1993). Yet, in terms of allocating responsibility, perhaps fining public bodies makes more sense than fining private companies. Politicians representing the concerns of taxpayers can put enormous pressure on prisons to reduce costs, without expressly encouraging illegal or unsafe actions, but without sufficiently resourcing these institutions to allow them to maintain safe conditions either. Imprisonment is the state's most powerful weapon of censure, designed to punish the most reprehensible of shared wrongs against the community, to reinforce the shared morality of that community (Marshall and Duff, 1998; Durkheim, 1964). The community is imposing the custodial sentence through the courts and thus it is at least arguable that the community should share the burden of responsibility for the conditions in which prisoners are detained too.

Yet wherever responsibility is attributed, it is difficult to avoid the conclusion that the criminal law - while necessary for holding corporations and public bodies criminally responsible when their gross negligence causes death - would have to be used much more extensively than it is at present to produce the level of deterrent effect required to prevent workplace fatalities or indeed deaths in custody (Almond, 
2013: 178). Although the law of corporate manslaughter may serve a dynamic social purpose by leading corporations and public bodies on the values that should inform certain kinds of individual, collective and organisational behaviour, criminalisation is insufficient to bring about fundamental change on its own. Perhaps it will only be when work-related fatalities and deaths in custody are recognised as pressing public health issues that feasible prevention strategies will emerge to reduce the number of avoidable deaths both in custody and in the workplace (Simon, 2010; Bonner, 2000: 374; Herber and Landrigan, 2005: 541-545). Politicians, legislators and members of the public, who rarely respond sympathetically to calls for prisoners' rights, may respond more enthusiastically if such problems are reconfigured in this way. 


\section{Bibliography}

Almond, P. (2013) Corporate Manslaughter and Regulatory Reform. Basingstoke: Palgrave Macmillan.

Ashworth, A. (2009) Principles of Criminal Law, $6^{\text {th }}$ ed. Oxford: Oxford University Press.

Ashworth, A. and Horder, J. (2013) Principles of Criminal Law, $7^{\text {th }}$ ed. Oxford: Oxford University Press.

Bonner, R.L. (2000) 'Correctional suicide prevention in the year 2000 and beyond', Suicide and Life-Threatening Behavior, 30: 370-376.

Brenner H.J. and Hopkins, J. (2006) Health and Quality in Work Final Report, Volume IV, Annex IV: Accidents at Work. Available at:

ec.europa.eu/social/BlobServlet?docld=2133\&langld=en.

Bureau of Labor Statistics (BLS). (1994-2013) Census of Fatal Occupational Injuries.

Available at: http://www.bls.gov/iif/osh_nwrl.htm\#cfoi.

Carolan. B. (2011) 'Criminalizing Corporate Killing; the Irish Approach', Stetson Law Review, 41: 157-74.

Clarkson, C. (2005) 'Corporate manslaughter: Yet more government proposals', Criminal Law Review, 9: 677-89.

Coffee, J. (1981) 'No Soul to Damn: No Body to Kick: An Unscandalized Inquiry into the Problem of Corporate Punishment', Michigan Law Review, 79: 386-459.

Commission for Racial Equality. (2003) The Murder of Zahid Mubarek (London: Commission for Racial Equality).

Corston, J. (2007) The Corston Report: A Report of a Review of Women with Particular Vulnerabilities in the Criminal Justice System. London: Home Office. Department of Transport. (1987) MV Herald of Free Enterprise. Report of Court no. 8074. Formal Investigation. London: HM Stationery Office.

Drummond, A. (2007) An Investigation into the Official Data Sources and Collection Methods. Available at:

www.hsa.ie/eng/Publications_and_Forms/.../Drummond_Study.pdf.

Drummond, A. (2008) A Review of the Occupational Disease Reporting System in the Republic of Ireland. Available at:

http://www.lenus.ie/hse/bitstream/10147/76879/1/Areviewofoccupational.pdf.

Durkheim, E. (1964) The Rules of Sociological Method. New York: Free Press.

Eurostat. (2012) Accidents at Work (ESAW, 2008 Onwards). Available at:

http://ec.europa.eu/eurostat/web/health/health-safety-work/data/database.

Field, S. and Jones, L. (2013) 'Five years on: the impact of the Corporate

Manslaughter and Corporate Homicide Act 2007: plus ca change?', International

Company and Commercial Law Review, 24: 239-246.

Field, S. and Jones, L. (2014) 'Are directors getting away with manslaughter?

Emerging trends in prosecutions for corporate manslaughter', Business Law Review, 35: 158-163.

Fisse, B. and Braithwaite, J. (1993) Corporations, Crime and Accountability.

Cambridge: Cambridge University Press.

Forlin, G. and Smail, L. (2013) Corporate Liability: Work Related Deaths and Criminal Prosecutions. West Sussex: Bloomsbury Professional. 
Gobert, J. (1994) 'Corporate Criminality: Four Models of Fault', Legal Studies, 14: 393-410.

Gobert, J. (2008a) 'The Corporate Manslaughter and Corporate Homicide Act 2007 Thirteen years in the making but was it worth the wait?', The Modern Law Review, 71: 413-433.

Gobert, J. (2008b) 'The Evolving Legal Test of Corporate Criminal Liability', in J. Minkesand L. Minkes (eds) Corporate and White-Collar Crime (London: Sage). Gobert, J. and Punch, M. (2003) Rethinking Corporate Crime. London: Butterworths. Griffin, S. and Moran, J. (2010) 'Accountability for Deaths Attributable to the Gross Negligent Act or Omission of a Police Force', Journal of Criminal Law, 74: 358-381. Health and Safety Authority (HAS). (2013) Annual Report 2012. Available at: http://www.hsa.ie/eng/Publications_and_Forms/Publications/Corporate/annual_re port_12.pdf.

Health and Safety Executive (HSE). (2015) Statistics on Fatal Injuries in the Workplace in Great Britain 2015. Available at:

http://www.hse.gov.uk/statistics/pdf/fatalinjuries.pdf.

Herber, R. and Landrigan, P.J. (2000) 'Work-related death: a continuing epidemic', American Journal of Public Health, 90: 541-545.

HM Chief Inspector of Prisons for England and Wales (HMCIP). (2014) Annual Report 2013-14 (London: Stationery Office). Available at:

https://www.justiceinspectorates.gov.uk/hmiprisons/wpcontent/uploads/sites/4/2014/10/HMIP-AR_2013-14.pdf.

Horan, S. (2011) Corporate Crime. Haywards Heath: Bloomsbury Professional. Horder, J. (2012) Homicide and the Politics of Law Reform. Oxford: Oxford University Press.

Hoskins, A.B. (2005) 'Occupational injuries, illnesses, and fatalities among women', Monthly Labour Review, 128: 31-7.

Jackall, R. (1988) Moral Mazes: The World of Corporate Managers. New York: Oxford University Press.

Keith, B. (2006) Report of the Zahid Mubarek Inquiry. London: Stationery Office. Kilcommins, S., O'Donnell, I., O'Sullivan, E. and Vaughan, B. (2004) Crime, Punishment and the Search for Order in Ireland. Dublin: Institute of Public Administration.

Law Reform Commission (LRC). (2003) Consultation Paper on Corporate Killing. Dublin: Stationery Office.

Law Reform Commission (LRC). (2005) Report on Corporate Killing. Dublin: Stationery Office.

Liebling, A. (2002) Suicides in Prison. London: Routledge.

Livingstone, S., Owen, T. Macdonald, A., Ní Ghrálaigh, B. and Law, H. (2008) Prison Law. Oxford: Oxford University Press.

Marshall, S.E. and Duff, R.A. (1998) 'Criminalisation and Sharing Wrongs', Canadian Journal of Law and Jurisprudence, 11: 7-22.

Matthews, R. (2008) Blackstone's Guide to the Corporate Manslaughter and Corporate Homicide Act 2007. Oxford: Oxford University Press.

McGrath, J. (2015) Corporate and White Collar Crime in Ireland: A New Architecture of Regulatory Enforcement. Manchester: Manchester University Press. 
McShee, D. (2008) 'The History of the Corporate Manslaughter and Corporate Homicide Act 2007', in A. Davies (ed.) Corporate Manslaughter and Corporate Homicide Act: Special Report. Cambridge: Workplace Law Group, pp. 9-16.

Ministry of Justice. (2014) Safety in Custody Statistics England and Wales Update to March 2014. Available at:

https://www.gov.uk/government/uploads/system/uploads/attachment_data/file/33 9067/safety-in-custody-to-mar-2014.pdf.

Ministry of Justice. (2015) Safety in Custody Quarterly Update to December and Annual. Available at: https://www.gov.uk/government/statistics/safety-in-custodyquarterly-update-to-december-2014-and-annual.

Minkes, J. and Minkes, L. (eds)(2008) Corporate and White-Collar Crime (London: Sage).

National Offender Management Service (NOMS). (2012) Fair and Sustainable: Revision to proposals for working structures in HM Prison Service following the Consultation with Trade Unions. City: Publishing House.

O'Donnell, I. (2002) 'Unlawful killing past and present', The Irish Jurist, 37: 56-90.

Office for National Statistics. (2012) Crime Statistics: Appendix Tables 2011-12, Crime in England and Wales, Quarterly First Release to March 2012. Available at:

http://www.ons.gov.uk/ons/publications/re-reference-

tables.html?edition=tcm\%3A77-265883.

Office for National Statistics. (2013) Crime Statistics: Appendix Tables - Focus on: Violent Crime and Sexual Offences, 2011/12. Table 1.02: Police recorded crime by offence, 1997 to 2011/12 and percentage change between 2010/11 and 2011/12. Available at: http://www.ons.gov.uk/ons/publications/re-reference-

tables.html?edition=tcm\%3A77-290621.

Office for National Statistics. (2015) Crime in England and Wales: Year Ending December 2014. Available at: http://www.ons.gov.uk/ons/dcp171778_401896.pdf. Ormerod, D. and Taylor, R. (2008) 'The Corporate Manslaughter and Corporate Homicide Act 2007', Criminal Law Review, 8: 589-611.

Owers, A. (2009) 'Prison Inspection and the Protection of Prisoner's Right', Pace Law Review, 30: 1535-47.

Prison and Probation Ombudsman for England and Wales (PPO). (2014a) Learning from PPO Investigations: Self-Inflicted Deaths of Prisoners on ACCT. Available at: http://www.ppo.gov.uk/wpcontent/uploads/2014/07/ACCT_thematic_final_web.pdf.

Prison and Probation Ombudsman for England and Wales (PPO). (2014b). Learning from PPO Investigations: Risk factors in Self-Inflicted Deaths in Prisons. Available at: http://www.ppo.gov.uk/wpcontent/uploads/2014/07/Risk_thematic_final_web.pdf.

Russell, H., Bertrand, M. and Watson, D. (2015) Trends and Patterns in Occupational Health and Safety in Ireland. Available at:

http://www.hsa.ie/eng/Publications_and_Forms/Publications/Corporate/Trends_an d_Patterns_in_Occupational_Health_and_Safety_in_Ireland.pdf.

Sealy, L. and Worthington, S. (2010) Sealy's Cases and Materials in Company Law, $9^{\text {th }}$ ed. Oxford: Oxford University Press.

Sentencing Guidelines Council. (2010) Corporate Manslaughter \& Health and Safety Offences Causing Death. Definitive Guideline. Available at: 
http://www.sentencingcouncil.org.uk/wp-

content/uploads/web_guideline_on_corporate_manslaughter_accessible.pdf.

Simon, J. (2010) 'Do these prisons make me look fat? Moderating the USA's

Consumption of Punishment', Theoretical Criminology, 14: 257-72.

Slapper, G. (2013) 'Justice is mocked if an important law is unenforced', Journal of

Criminal Law, 77: 91-4.

Ussher, P. (1986) Company Law in Ireland. London: Sweet and Maxwell.

Wells, C. (2001) Corporations and Criminal Responsibility, $2^{\text {nd }}$ ed. Oxford: Oxford University Press.

Wells, C. (2014) 'Corporate Criminal Liability: a ten year review', Criminal Law

Review, 12: 849-78.

Wolgast, E. (1992) Ethics of an Artificial Person: Lost Responsibility in Professions and Organisations. California: Stanford University Press.

\section{Legislation and Statutory Instruments}

The Corporate Manslaughter and Corporate Homicide Act 2007.

The Corporate Manslaughter and Corporate Homicide Act 2007 (Commencement No. 3) Order 2011 (SI 2011/1867).

\section{Parliamentary Debates}

688 HL Official Report ( $5^{\text {th }}$ Series), col GC 187.

688 HL Official Report ( $5^{\text {th }}$ Series), col GC 192. 
Table 1: Standardised Incidence Rates of Fatal Accidents at Work in the EU15 Countries, 2012.

\begin{tabular}{|c|c|c|c|}
\hline EU15 Countries & $\begin{array}{c}\text { Total } \\
\text { Rate (Number) }\end{array}$ & $\begin{array}{c}\text { Men } \\
\text { Rate (Number) }\end{array}$ & $\begin{array}{c}\text { Women } \\
\text { Rate (Number) }\end{array}$ \\
\hline United Kingdom & $0.58(85)$ & $0.88(83)$ & $2(0.05)$ \\
\hline Netherlands & $0.72(26)$ & $1.09(26)$ & $0.0(0)$ \\
\hline Sweden & $0.8(21)$ & $1.12(20)$ & $0.18(1)$ \\
\hline Germany & $0.9(258)$ & $1.45(247)$ & $0.1(11)$ \\
\hline Denmark & $1.18(20)$ & $1.85(20)$ & $0.0(0)$ \\
\hline Greece & $1.2(18)$ & $1.88(18)$ & $0.0(0)$ \\
\hline Italy & $1.29(237)$ & $1.98(233)$ & $0.07(4)$ \\
\hline Ireland & $1.43(18)$ & $2.19(18)$ & $0.0(0)$ \\
\hline Belgium & $1.46(30)$ & $2.27(30)$ & $0.0(0)$ \\
\hline Finland & $1.62(23)$ & $2.55(22)$ & $0.13(1)$ \\
\hline Spain & $1.99(168)$ & $3.18(165)$ & $0.1(3)$ \\
\hline Austria & $2.37(51)$ & $3.91(51)$ & $0.0(0)$ \\
\hline France & $2.64(350)$ & $4.05(328)$ & $0.4(22)$ \\
\hline Portugal & $2.71(91)$ & $4.36(88)$ & $0.28(3)$ \\
\hline Luxembourg & $2.91(6)$ & $4.57(6)$ & $0.0(0)$ \\
\hline EU 15 & $\mathbf{1 . 3 ( 1 4 0 2 )}$ & $\mathbf{2 . 0 2 ( 1 3 5 5 )}$ & $\mathbf{0 . 1 3 ( 4 7 )}$ \\
\hline
\end{tabular}


Figure 1: HMPS Organisational Structure since the introduction of the Fair and Sustainable working structures in April 2013.

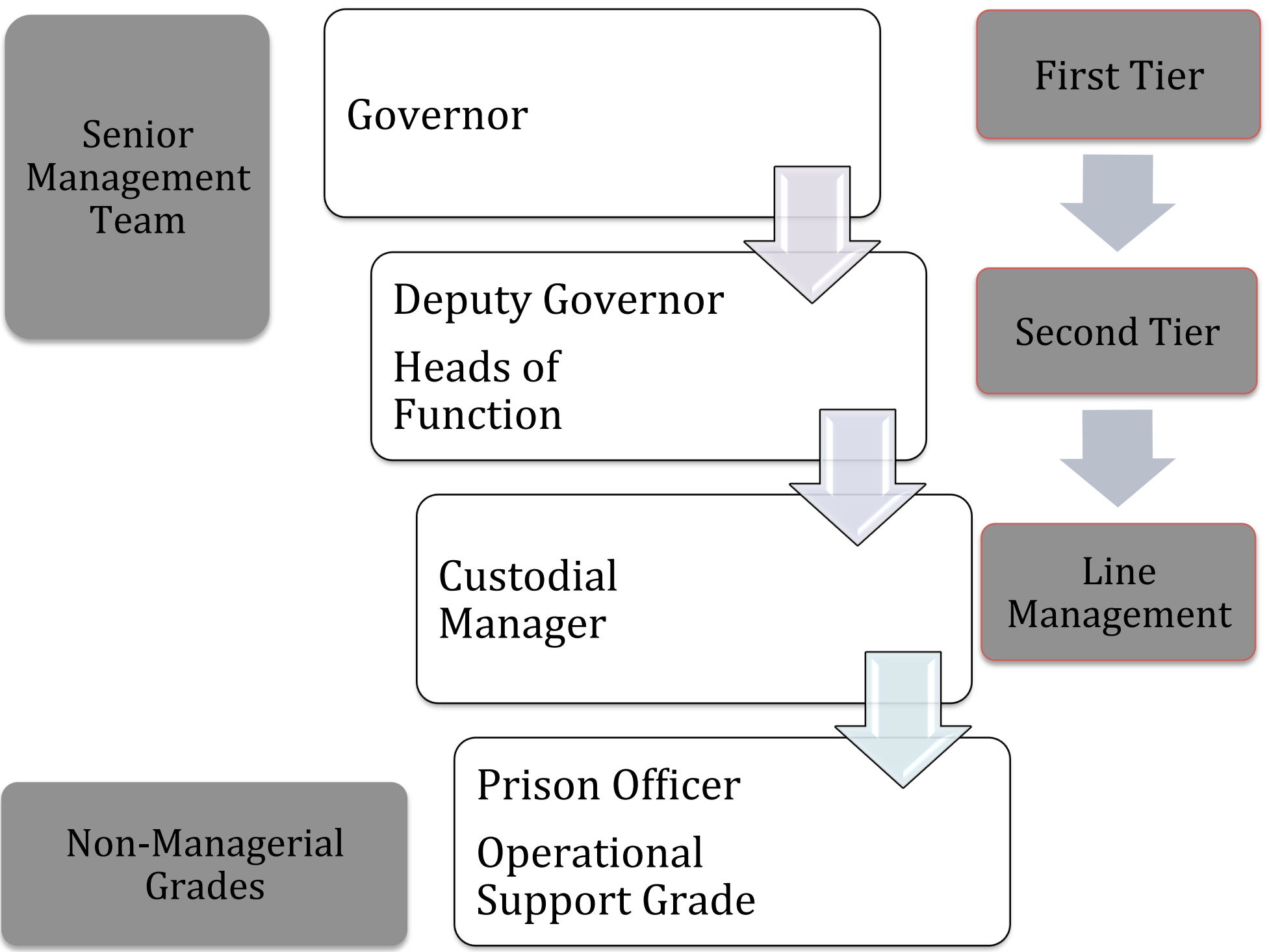

